\title{
Streptococcus mutans Dental Carries among Patients Attending Jimma University Specialized Hospital, Ethiopia
}

\author{
Demissew Shenkute, Tsegahun Asfaw \\ Department of Medical Laboratory Science, Debre Berhan University, Debre Berhan, Ethiopia
}

*Corresponding Author: Tsegahun Asfaw, Department of Medical Laboratory Science, Debre Berhan

\begin{abstract}
Dental caries is an irreversible microbial disease of the calcified tissues of the teeth. Streptococcus mutans is a bacterial resident of the oral cavity and is considered to be the principal etiological agent of dental caries in humans. Therefore, the aim of this study was to determine the prevalence and risk factors associated with streptococcus mutans dental caries. A cross sectional study was conducted among patients who attendeded Jimma University specialized hospital detal clinic. patintes demographic and clinical information was collected by using pre-tested questionnaire Dental plaques from all patients was picked up by forceps and suspended in to phosphate-buffered saline for further streptococcus mutans identification. From a total of 115 study participants 56(48.7\%) and 59(51.3\%) were males and females respectively. The overall prevalence of streptococcus mutanswas 79(68.7\%) among patients with dental carries. Twenty-five (21.7\%) participants had gem bleeding and 47 (40.9\%) participants had previous tooth decay. In this study, streptococcus mutans is the common public health problem among dental carries patients. Taking soft drinks, oral debris and gingival index were risk factor for dental caries of streptococcus mutans.
\end{abstract}

Keywords: Streptococcus mutans, Dental Carries, Ethiopia

\section{INTRODUCTION}

Dental plaque is an adherent deposit of bacteria and their products, which forms as a white greenish or even yellow film on all tooth surfaces. Dental plaque accumulates naturally at stagnant or retentive sites formed after one or two days with no oral hygiene (Nada HA et al., 2008).Dental caries is the single most prevalent and costly infectious disease worldwide, affecting more than $90 \%$ of the population in the US. The development of dental cavities requires the colonization of the tooth surface by acid producing bacteria such as Streptococcus mutans, in conjunction with the frequent ingestion of a cariogenic high sucrose diet, the substrate for acid and glucan production by organisms. The elevated amounts of acid and glucans modulate the establishment of cariogenic organisms within tightly adherent biofilms known as dental plaque (Catalan MA et al., 2011). Tooth surfaces colonized with S. mutans are at a higher risk for developing caries (Pannu P. et al., 2013).Dental caries is an irreversible microbial disease of the calcified tissues of the teeth, which is characterized by demineralization of the inorganic portion and destruction of the organic substance of the tooth, which often leads to cavitation. Dental caries is a multifactorial disease, which is caused by host, agent, and environmental factors (Kt S. et al., 2013).Streptococcus mutansare gram positive cocci bacteria. These facultative anaerobes are commonly found in the human oral cavity. It grow at temperatures of between $18-40^{\circ}$. Streptococcus mutans are a cariogenic microorganism that breaks down sugar for energy and produces an acidic environment, which dematerializes the superficial structure of the tooth. The result of the conversion disintegrates the coating of the tooth then later dissolves the calcium molecule creating hole (Whiley RA. and Beighton D. 2013; Jav ND. et al., 2013).It can be isolated from individuals either with or without a history of caries, but the development of dental carries dependent on the bacterial load strain variation of Streptococcus mutans (Smith B et al., 19998; Zhang L. et al., 2009).

\section{MATERIAL AND MethodS}

\subsection{Study Area and Period}

The study was conducted at Jimma University specialized hospital, which is located around $352 \mathrm{~km}$ Southwest of Addis Ababa. The study was conducted from March, 2017 to August, 2018. 


\subsection{Study Design}

A cross sectional study design was conducted.

\subsection{Inclusion and Exclusion Criteria}

All patients attending dental clinic of Jimma University specialized hospitalwith clinical manifestation of dental caries and who are volunteer and able to give sample were included. Patients who are taking antibiotics in the last 30dayswere excluded.

\subsection{Sample Size and Sampling Technique}

The sampling technique was based on convenient sampling method. The sample size was all patients with clinical manifestation of dental caries who were visited Jimma University specialized hospital dental clinic and fulfill inclusion criteria.

\subsection{Data Collection Methods}

Patients socio demographic and clinical information was collected by using pre-tested questionnaire. All study participants wasexamined by dental doctor.Dental plaques from all patients were picked up through forceps (probe) and transferred into $2 \mathrm{ml}$ of sterile tube containing phosphate-buffered saline and processed immediately after collection in Jimma university microbiology laboratory (Teresa CC. et al., 2007).

\subsection{Isolation and Identification of S.mutans}

The dental plaque suspension was vortexed for 30s for homogenization. Then a volume of $100 \mu 1$ was spread onto Mitis-salivaris (MS-agar) by using sterile cotton swab and incubated in $5 \% \mathrm{CO}_{2}$ for 48 hours at $37^{\circ} \mathrm{C}$. A colony count of more than $250\left(10^{4}\right.$ cells $\left./ \mathrm{ml}\right)$ was considered as positive samples. Small colony was sub-cultured on blood-agar plates for further identification. A gram positive cocci, alpha hemolytic on blood agar, catalase negative, mannitol andlactose fermenters was considered as Streptococcus mutans (Nada HA. et al., 2008; Cockerill FR. et al., 2011).

\subsection{Data Entry and Analysis}

Data was edited, cleaned and checked for its completeness and entered to SPSS version 21 for analysis. Patients' Socio-demographic and clinical characteristics were described by using descriptive statistics. Bivariate and multivariate logistic regression analysis were done and P-value less than 0.05 was taken as statistically significant.

\subsection{Ethical Consideration}

Ethical clearance was obtained from Jimma University Ethical Review Board. Letter of permission was secured from Jimma University specialized hospital management. Written informed consent and assent was obtained from the study participants. Any information concerning the patients was kept confidential and patients with positive result were communicated for further managment.

\subsection{Quality Control}

To assure the quality of the data, standard operating procedure was followed during media preparation and other laboratory procedures. Sterility check was performed to avoid the possibility of contamination. All reagents was checked for their expiry date and prepared according to the manufacturer's instruction.

\section{RESULT}

Among 115 study participants, the overall prevalence of Streptococcus mutans dental caries was 79 $(68.7 \%)$.

\subsection{Socio-demographic Characteristics of the of the Participants}

Among 115 participants, 56(48.7\%) were males and 59(51.3\%) were females. The mean age of the participants was 32.67 years with standard deviation $(\mathrm{SD}=1.48)$. Among participants $64(55.7 \%)$ and $51(44.3 \%)$ of the participants were come from urban and rural area respectively. Regarding occupation $17(14.8 \%)$ of them were housewife followed by farmer 13(11.3\%). Majority of the respondents $34(49.3 \%$ ) were completed grade 12 (Table 1 ). 
Streptococcus mutans Dental Carries among Patients Attending Jimma University Specialized Hospital, Ethiopia

Table1. socio-demographic characteristics of patients attending dental clinic of Jimma University Specialized Hospital from March, 2017 to August, 2018

\begin{tabular}{|c|c|c|c|c|}
\hline \multirow{2}{*}{\multicolumn{2}{|c|}{ Socio- demographic Characteristics }} & \multicolumn{2}{|c|}{ Culture result forStreptococcus mutans } & \multirow{2}{*}{$\begin{array}{l}\text { TotalNO } \\
(\%)\end{array}$} \\
\hline & & Positive NO $(\%)$ & Negative NO $(\%)$ & \\
\hline \multirow[t]{2}{*}{ Sex } & Male & $43(37.4)$ & $13(11.3)$ & $56(48.7)$ \\
\hline & Female & $36(31.3)$ & $23(20.0)$ & $59(51.3)$ \\
\hline \multirow[t]{2}{*}{ Place of residence } & Urban & $41(35.7)$ & $23(20.0)$ & $64(55.7)$ \\
\hline & Rural & $38(33.0)$ & $13(11.3)$ & $51(44.3)$ \\
\hline \multirow[t]{7}{*}{ Occupation } & Farmer & $11(9.6)$ & $2(1.7)$ & $13(11.3)$ \\
\hline & Merchant & $6(5.2)$ & $5(4.3)$ & $11(9.6)$ \\
\hline & Employed & $10(8.7)$ & $7(6.1)$ & $17(14.8$ \\
\hline & Unemployed & $3(2.6 \%)$ & $1(0.9)$ & $4(3.5)$ \\
\hline & Housewife & $11(9.6)$ & $6(5.2)$ & $17(14.8)$ \\
\hline & Driver & $1(0.9)$ & $0(0)$ & $1(0.9)$ \\
\hline & Other & $37(32.2)$ & $15(13.0)$ & $52(45.2)$ \\
\hline \multirow[t]{6}{*}{ Educational status } & Illiterate & $36(31.3)$ & $10(8.7)$ & $46(40.0)$ \\
\hline & Read \&write only & $2(2.9)$ & $3(4.3)$ & $5(7.2)$ \\
\hline & 1-4 grade & $5(7.2)$ & $5(7.20$ & $10(14.5)$ \\
\hline & $5-8$ grade & $7(10.1)$ & $1(1.4)$ & $8(11.6)$ \\
\hline & $9-12$ grade & $7(10.1)$ & $5(7.2)$ & $12(17.4)$ \\
\hline & Above 12 & $22(31.9)$ & $12(17.4)$ & $34(49.3)$ \\
\hline
\end{tabular}

\subsection{Knowledge and Practice on Tooth Cleaning Habit of the Respondents}

From115 participants 73(63.5\%) were cleaned their teeth and among these 73(63.5\%), 40(54.8\%) were used tooth stickand tooth brush respectively. From respondents who cleaned their teeth more than half of them were cleaned their teeth in sideway (horizontally) and also most of the participants were cleaned their tooth after meal and morning only. Very few were cleaned their teeth morning and before going to bed (Table 2).

Table2. Knowledge and practice on tooth cleaning habit of patients attending dental clinic of Jimma University Specialized Hospital from March, 2017 to April 2018

\begin{tabular}{|c|c|c|c|c|}
\hline \multicolumn{2}{|c|}{ Knowledge and practice on oral health } & \multicolumn{3}{|c|}{ Culture result for Streptococcus mutans } \\
\hline \multirow{3}{*}{ Habit of cleaning teeth } & & \multirow{2}{*}{$\begin{array}{l}\text { Positive } \\
\text { NO (\%) } \\
47(40.9)\end{array}$} & \multirow{2}{*}{$\begin{array}{l}\text { Negative } \\
\text { NO (\%) } \\
26(22.6)\end{array}$} & \multirow{2}{*}{$\begin{array}{l}\begin{array}{l}\text { Total NO } \\
(\%)\end{array} \\
73(63.5)\end{array}$} \\
\hline & Yes & & & \\
\hline & No & $32(27.8)$ & $10(8.7)$ & $42(36.5)$ \\
\hline \multirow{4}{*}{$\begin{array}{l}\text { Materials used to clean } \\
\text { teeth }\end{array}$} & Tooth Stick & $28(38.4)$ & $12(16.4)$ & $40(54.8)$ \\
\hline & Charcoal & $1(1.4)$ & $2(2.7)$ & $3(4.1)$ \\
\hline & Tooth brush \& rinse with water & $9(12.3)$ & $8(11.0)$ & $17(23.3)$ \\
\hline & Others & $9(12.3)$ & $4(5.5)$ & $13(17.8)$ \\
\hline \multirow{5}{*}{$\begin{array}{l}\text { Frequency of cleaning } \\
\text { teeth }\end{array}$} & Once a day & $22(30.1)$ & $4(5.5)$ & $26(35.6)$ \\
\hline & After each meal & $2(2.7)$ & $3(4.1)$ & $5(6.8)$ \\
\hline & Before and after each meal & $2(2.7)$ & $3(4.1)$ & $5(6.8)$ \\
\hline & More than once a day & $3(4.1)$ & $4(5.5)$ & $7(9.6)$ \\
\hline & Irregularly & $18(24.7)$ & $12(16.4)$ & $30(41.1)$ \\
\hline \multirow{4}{*}{ Way of cleaning teeth } & Top to bottom & $6(8.2)$ & $5(6.8)$ & $11(15.1)$ \\
\hline & Side way & $23(31.5)$ & $10(13.7)$ & $33(45.2)$ \\
\hline & Mixed & 16(21.9) & $11(15.1)$ & $27(37.0)$ \\
\hline & Circular & $2(2.7)$ & $0(0.0)$ & $2(2.7)$ \\
\hline \multirow[t]{5}{*}{ Time of brushing teeth } & Morning only & $13(17.8)$ & $10(13.7)$ & $23(31.5)$ \\
\hline & After meal & 16(21.9) & $8(11.0)$ & $24(32.9)$ \\
\hline & Before meal & $3(4.1)$ & $0(0.0)$ & $3(4.1)$ \\
\hline & Before going to bed & $2(2.7)$ & $0(0.0)$ & $2(2.7)$ \\
\hline & Irregular & $11(15.1)$ & $8(11.0)$ & $19(26.1)$ \\
\hline
\end{tabular}

\subsection{Associated Risk Factor for Dental Caries}

Sixteen (13.9\%) and 8(7.0\%) of the study participants had a habit of drinking alcohol and smoking cigarette respectively. Twenty eight $(24.3 \%)$ of the participants had a habit of chewing chat. Seventy 
Streptococcus mutans Dental Carries among Patients Attending Jimma University Specialized Hospital, Ethiopia

two $(62.6 \%)$ of the participants had a habit of taking sweet in take or food. Twenty two $(30.6 \%)$ of the participants were taking sweet intake irregularly. Eighty one (70.4\%) of the participants had a habit of taking soft drink and significantly associated with Streptococcusmutans dental carries $(\mathrm{p}=0.01)$ (Table: 3).

Table3. Associated risk factor for dental caries in patients attending dental clinic of Jimma University Specialized Hospital from March, 2017 to April 2018

\begin{tabular}{|c|c|c|c|c|c|}
\hline \multirow{2}{*}{\multicolumn{2}{|c|}{ Associated risk factor }} & \multicolumn{3}{|c|}{ Culture result Streptococcus mutans } & \multirow{2}{*}{$\begin{array}{l}\mathrm{P}- \\
\text { value }\end{array}$} \\
\hline & & \multirow{2}{*}{\begin{tabular}{|l}
$\begin{array}{l}\text { Positive No } \\
(\%)\end{array}$ \\
$13(11.3)$ \\
\end{tabular}} & \multirow{2}{*}{$\begin{array}{l}\begin{array}{l}\text { Negative } \\
\text { No }(\%)\end{array} \\
3(2.6)\end{array}$} & \multirow{2}{*}{$\begin{array}{l}\begin{array}{l}\text { Total No } \\
(\%)\end{array} \\
16(13.9) \\
\end{array}$} & \\
\hline \multirow[t]{2}{*}{ Habit of drinking alcohol } & Yes & & & & \multirow[t]{2}{*}{0.24} \\
\hline & No & \begin{tabular}{|l|}
$66(57.4)$ \\
\end{tabular} & $33(28.7)$ & $99(86.1)$ & \\
\hline \multirow{3}{*}{$\begin{array}{l}\text { Frequency of drinking } \\
\text { alcohol }\end{array}$} & Always & $0(0.0)$ & $1(6.2)$ & $1(6.2)$ & \multirow[t]{3}{*}{0.10} \\
\hline & Sometimes & $6(37.5)$ & $1(6.2)$ & $7(43.8)$ & \\
\hline & Rarely & $7(43.8)$ & $1(6.2)$ & $8(50)$ & \\
\hline \multirow[t]{2}{*}{ Habit of smoking cigarette } & Yes & $8(7)$ & $1(0.9)$ & $9(7.8)$ & \multirow[t]{2}{*}{0.17} \\
\hline & No & 71(61.7) & $35(30.4)$ & $106(92.2)$ & \\
\hline \multirow{3}{*}{$\begin{array}{l}\text { Frequency of smoking } \\
\text { cigarette }\end{array}$} & Regularly & $5(55.6)$ & $0(0.0)$ & $5(55.6)$ & \multirow[t]{3}{*}{0.32} \\
\hline & Occasionally & $3(33.3)$ & $0(0.0)$ & $3(33.3)$ & \\
\hline & Rarely & $0(0.0)$ & $1(11.1)$ & $1(11.1)$ & \\
\hline \multirow{2}{*}{ Habit chewing chat } & Yes & $23(20)$ & $5(4.3)$ & $28(24.3)$ & \multirow[t]{2}{*}{0.08} \\
\hline & No & 56(48.7) & $31(27.0)$ & $87(75.7)$ & \\
\hline \multirow[t]{3}{*}{ Frequency of chewing chat } & Regularly & $8(28.6)$ & $1(3.6)$ & $9(32.6)$ & \multirow[t]{3}{*}{0.40} \\
\hline & Occasionally & \begin{tabular}{|l|}
$12(42.9)$ \\
\end{tabular} & $2(7.1)$ & $14(50.0)$ & \\
\hline & Rarely & $3(10.7)$ & $2(7.1)$ & $5(17.9)$ & \\
\hline \multirow{2}{*}{$\begin{array}{l}\text { Habit of taking sweet intakes } \\
\text { or food }\end{array}$} & Yes & $46(40)$ & $26(22.6)$ & $72(62.6)$ & \multirow[t]{2}{*}{0.15} \\
\hline & No & \begin{tabular}{|l|}
$33(28.7)$ \\
\end{tabular} & $10(8.7)$ & 43(37.4) & \\
\hline \multirow[t]{6}{*}{ Kind of sweet intake } & Chocolate & $0(0.0)$ & $3(4.2)$ & $3(4.2)$ & \multirow[t]{6}{*}{0.20} \\
\hline & Candy & $1(1.4)$ & $1(1.4)$ & $2(2.8)$ & \\
\hline & Sugar cane & $6(8.3)$ & $3(4.2)$ & $9(12.5)$ & \\
\hline & Sugared coffee & $21(29.1)$ & $8(11.1)$ & $29(40.3)$ & \\
\hline & Sugared tea & $12(16.7)$ & $9(12.5)$ & $21(29.2)$ & \\
\hline & Others & $6(8.3)$ & $2(2.8)$ & $8(11.1)$ & \\
\hline \multirow{6}{*}{$\begin{array}{l}\text { Frequency of taking sweet } \\
\text { intake }\end{array}$} & Once a day & $13(18.1)$ & $3(4.2)$ & $16(22.2)$ & \multirow[t]{6}{*}{0.15} \\
\hline & After each meal & $8(11.1)$ & $1(1.4)$ & $9(12.5)$ & \\
\hline & More than once a day & $12(16.7)$ & $10(13.9)$ & $22(30.6)$ & \\
\hline & Irregularly & $12(16.7)$ & $10(13.9)$ & $22(30.6)$ & \\
\hline & Every other day & $1(1.4)$ & $1(1.4)$ & $2(2.8)$ & \\
\hline & Once time per week & $0(0.0)$ & $1(1.4)$ & $1(1.4)$ & \\
\hline \multirow[t]{2}{*}{ Habit of taking soft drinks } & Yes & \begin{tabular}{|l|}
$50(43.5)$ \\
\end{tabular} & $31(27.0)$ & $81(70.4)$ & \multirow[t]{2}{*}{0.01} \\
\hline & $\mathrm{NO}$ & $29(25.2)$ & $5(4.3)$ & $34(9.6)$ & \\
\hline frequency of taking soft drink & Regularly & $3(3.7)$ & $4(4.9)$ & $7(8.6)$ & 0.26 \\
\hline & Occasionally & \begin{tabular}{|l|}
$28(34.6)$ \\
\end{tabular} & $12(14.8)$ & $40(49.4)$ & \\
\hline & Rarely & $19(23.5)$ & $15(18.5)$ & $34(42.0)$ & \\
\hline presence xerostomia & Yes & $4(3.5)$ & $0(0.0)$ & $4(3.5)$ & 0.17 \\
\hline & No & \begin{tabular}{|l|}
$75(65.2)$ \\
\end{tabular} & $36(31.3)$ & 111(100) & \\
\hline Diabetes mellitus & Yes & $15(13.0)$ & $4(3.5)$ & $19(16.5)$ & 0.29 \\
\hline & No & \begin{tabular}{|l|}
$64(55.7)$ \\
\end{tabular} & $32(27.8)$ & $96(83.5)$ & \\
\hline
\end{tabular}

\subsection{Clinical Data on Oral Health}

Among a total of 115 participants, 25(21.7\%) had gem bleeding and 47 (40.9\%) of the participants had previous tooth decay. Nearly more than half the respondents had oral debris covering not more than one third of the tooth surface. Only $42(36 \%)$ were free from oral debris. Oral debris has statistically significance association with Streptococcus mutans dental caries $(\mathrm{P}=0.022)$.

Most of the participants, 55(47.8\%) had normal gingival index and 50(43.5\%) had mild inflammation but only $1(0.9 \%)$ had sever inflammation. Gingival index has statistically significant association with Streptococcus mutans dental caries $(\mathrm{P}=0.002)$. Fifty eight $(50.4 \%)$ of the participant had no calculus index and41 (35.7\%) had mild super gingival calculus. Only few 3(2.6\%) had excessive supra and sub gingival calculus (Table 4). 
Streptococcus mutans Dental Carries among Patients Attending Jimma University Specialized Hospital, Ethiopia

Table4. Clinical finding in patients attending dental clinic of Jimma University Specialized Hospital from March, 2017 to April 2018

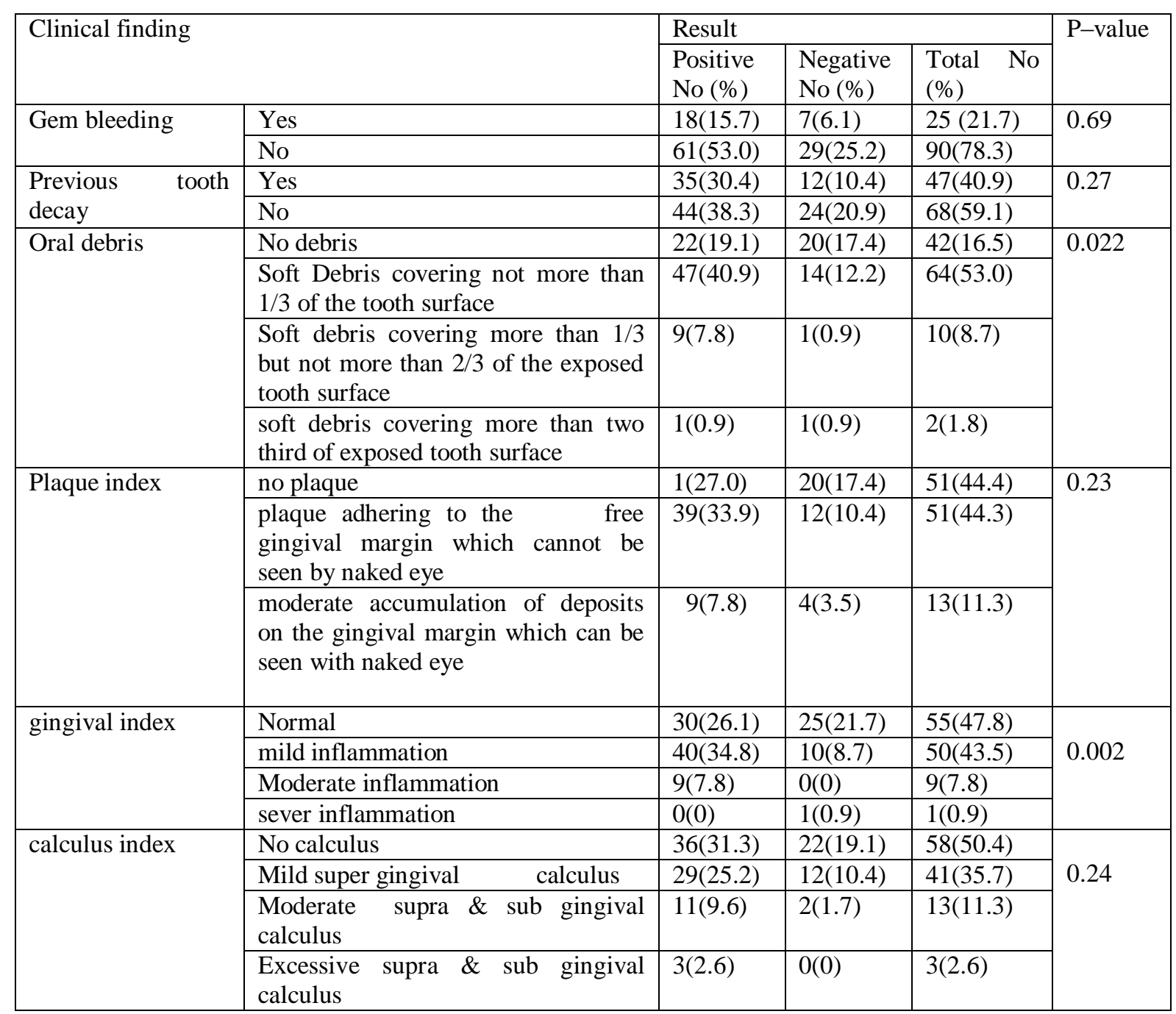

\section{Class of Tooth Decay}

From 47 tooth decay cases, 21 (44.7\%) of them had class I followed by class II 17(36.2\%) (Table 5).

Table5. Frequency of class of tooth decaying patients attending dental clinic of Jimma University Specialized Hospitalwith culture results for Streptococcus mutans

\begin{tabular}{|l|l|}
\hline Class of tooth decay & Frequency No (\%) \\
\hline Class I & $21(44.7)$ \\
\hline Class II & $17(36.2)$ \\
\hline Class III & $4(8.5)$ \\
\hline Class IV & $2(4.3)$ \\
\hline Class V & $3(6.4)$ \\
\hline Total & $47(100)$ \\
\hline
\end{tabular}

\section{DISCUSSION}

In Ethiopia, there is scarcity of data on Streptococcus mutans dental caries. In this study Streptococcus mutans dental caries is the major public health problem among patients attending dental clinic of Jimma University specialized hospital. The prevalence of Streptococcus mutans dental caries was found to be $68.7 \%$ which is comparable with a study conducted in Brazil (68.5\%) (Costa SM. et al., 2012), China (67.5\%) (Liu L. et al., 2013) and Srilanka (68.8\%) (Perera PJ. et al., 2012).However, it was lower than study conducted in Qatar (85\%) (Al-Darwish M. et al., 2014). It was higher than study conducted in in Gondar, Ethiopia (36.3\%) (Ayele FA. et al., 2013).The difference might be due to the difference in knowledge and practice of oral hygiene. 
Habit of taking soft drink was found to be statistically significance association with Streptococcus mutans dental caries. This also supported by similar findings done in India and Zimbabwe respectively (Prasai Dixit L. et al., 2013; Sukhabogi J. et al., 2014).This also might be associated with acid production by cariogenic organism such as Streptococcus mutans that adhere to teeth as result of fermentation of soft drink. Later the enamel of tooth went to tooth decay.

In this study, the highest prevalence was seen in urban area 41(35.7\%) than rural 38(33.0\%).This finding was in agreements with a study done in Zimbabwe (Prasai Dixit L. et al., 2013). The possible reason for this also might be due to the habit of urban population taking soft drink and food. Oral debris has statistically significant association with Streptococcus mutans dental caries. This finding also conforms other findings (Mafuvadze BT. et al., 2013).Moreover; gingival index have significant association with Streptococcus mutans dental caries. This also might be a good indicator of poor oral hygiene practices (TS. Kumar et al., 2013; Nobile CG. et al., 2014).Because gingival index increase Streptococcus mutans colonization and in severe cases it involves loses of the enamel.

In this study drinking alcohol, smoking cigarette, plaque index and calculus index and chewing chat has no significant association with Streptococcus mutans dental caries. The reason for this discrepancy might be short data collection period and small number of the study population.

\section{CONCLUSION AND RECOMMENDATION}

Dental caries of streptococcus mutans is the common public health problem among patients attending at dental clinic of Jimma University specialized hospital. Soft drinks, oral debris and gingival index are the associated risk factor for Streptococcus mutans dental caries. Health education on oral hygiene, dietary habit and dental clinic visit should be given to prevent and control Streptococcus mutans dental caries.

\section{AUTHORS' CONTRIBUTIONS}

DS-performed the laboratory activities. DS- analyzed the data. TA-wrote the manuscript. All authors read and approved the final manuscript.

\section{REFERENCES}

Nada HA. Al-Mudallal, Essam FA. Al-Jumaily, Nidhal AA. Muhimen and Abd Al-Wahid Al-Shaibany (2008).Isolation and identification of mutan's streptococci bacteria from human dental plaque samples. Journal of Al-Nahrain University,11(3),98-105

Catalán MA, Scott-Anne K, Klein MI, Koo H, Bowen WH, Melvin JE. (2011). Elevated Incidence of Dental Caries in a Mouse Model of Cystic Fibrosis Sample. PLoS ONE, 6(1):e16549.

Pannu P, Gambhir R, Sujlana A. (2013). Correlation between the salivary Streptococcus mutans levels and dental caries experience in adult population of Chandigarh, India.European Journal of Dentistry,7(2),191195.

Kt S, Kmk M, NB, Jimson S, RS. (2013). Dental Caries Vaccine - A Possible Option?Journal of Clinical and Diagnostic Research, 7(6), 1250-1253.

Whiley RA. and Beighton D.(2013). "Streptococci and Oral Streptococci." Bite-Sized Tutorials.N.p.Web.

Jav ND, Webed M, Chaudhry S, Butt S, Ijaz S, Asad R, Awais F, and Khan A. (2013). "Transmission of Streptococcusmutans from Mother to Child." Review Article. Pakistan and Oral Dental Journal, 32 (3).

Smith B, Pickard HM, Kidd EAM. (1990). "Why restore teeth?" Pickard's manual of operative dentistry,(6th $\mathrm{Ed})$.

Zhang L, Foxman B, Drake DR, et al. (2009). Comparative whole-genome analysis of Streptococcus mutans isolates within and among individuals of different caries status. Oral microbiology and immunology, 24(3), 197-203.

Teresa CC. Franco EF, Patrícia A, José Moacir M. Fernando ADA. (2007). Detection of Streptococcus mutans and Streptococcus sobrinus in Dental Plaque Samples from Brazilian Preschool Children by Polymerase Chain Reaction Brazil Dental Journal, 18(4), 329-333

Cockerill FR, Wikler MA, Bush K, Dudley MN, Eliopoulos GM, Hardy DJ, et al.(2011). Performance Standards for Antimicrobial Susceptibility Testing Twenty-First Informational Supplement.

Costa SM, Vasconcelos M, Haddad JPA, Abreu MHN. (2012). the severity of dental caries in adults aged 35 to 44 years residing in the metropolitan area of a large city in Brazil: a cross-sectional study. BMC Oral Health, 12, 25. 
Liu L, Zhang Y, Wu W, Cheng M, Li Y, Cheng R. (2013). Prevalence and Correlates of Dental Caries in an Elderly Population in Northeast China. PLoS ONE, 8(11).

Perera PJ, Abeyweera NT, Fernando MP, Warnakulasuriya TD, Ranathunga N.(2012). Prevalence of dental caries among a cohort of preschool children living in Gampaha district, Sri Lanka: A descriptive cross sectional study. BMC Oral Health, 12, 49.

Al-Darwish M, El Ansari W, Bener A. (2014). Prevalence of dental caries among 12-14year old children in Qatar. The Saudi Dental Journal, 26(3), 115-125.

Ayele FA, Taye BW, Ayele TA, Gelaye KA. (2013). Predictors of Dental caries among children 7-14 years old in Northwest Ethiopia: a community based cross-sectional study. BMC Oral Health, 13:7.

Sukhabogi J, Parthasarathi P, Anjum S, Shekar B, Padma C, Rani A. (2014). Dental Fluorosis and Dental Caries Prevalence among 12 and 15-Year-Old School Children in Nalgonda District, Andhra Pradesh, India. Annals of Medical and Health Sciences Research, 4(Suppl 3).

Prasai Dixit L, Shakya A, Shrestha M, Shrestha A. (2013). Dental caries prevalence, oral health knowledge and practice among indigenous Chepang school children of Nepal. BMC Oral Health, 13, 20.

Mafuvadze BT, Mahachi L, Mafuvadze B. (2013). Dental caries and oral health practice among 12 year old school children from low socio-economic status background in Zimbabwe. The Pan African Medical Journal, 14, 164.

T S. Kumar, BS, Datta M, V.T. H, Nisha VA. (2013). Prevalence, Severity and Associated Factors of Dental Caries in 3-6 Year Old Children. Journal of Clinical and Diagnostic Research, 7(8), 1789-1792.

Nobile CG, Fortunato L, Bianco A, Pileggi C, Pavia M. (2014). Pattern and severity of early childhood caries in Southern Italy: a preschool-based cross-sectional study. BMC Public Health, 14-206.

Citation: Demissew Shenkute \& Tsegahun Asfaw "Streptococcus mutans Dental Carries among Patients Attending Jimma University Specialized Hospital, Ethiopia" International Journal Of Research Studies In Biosciences (Ijrsb), Vol. 7, no. 2, pp. 49-55, 2019. http://Dx.Doi.org/10.20431/2349-0365.0702005

Copyright: (C) 2019 Authors. This is an open-access article distributed under the terms of the Creative Commons Attribution License, which permits unrestricted use, distribution, and reproduction in any medium, provided the original author and source are credited. 